\title{
鉄骨骨組の全体崩壊機構に要求される柱・梁耐力比に関する一考察 AN INVESTIGATION ON THE COLUMN OVER-DESIGN FACTORS FOR STEEL FRAMED STRUCTURES
}

\author{
趙 衍 剛*, 小野徹郎**, 石井 清***, 吉原和 宏**** \\ Yan-Gang ZHAO, Tetsuro ONO, Kiyoshi ISHII \\ and Kazuhiro YOSHIHARA
}

\begin{abstract}
In the earthquake resistance design of frame structures, it is a general requirement to give a suitable target value of the column over-design factor (COF) for which the occurrence probability of unpreferable failure modes can be limited to within a specific tolerance. In the present paper, the likely failure modes of weak-beam-strong-column designed structures under uncertain loads and with uncertain member strengths are investigated and the target value of COF is discussed in probabilistic terms under three failure levels, i.e., Level 1 -- strictly beam-hinging pattern, Level 2-- beam-hinging pattern and Level 3 -- total collapse pattern. It was found that :(1) For levels 1 and 2, the larger the number of bays and stories, the larger the target value of the COF. For level 3, the target value of the COF is independent of the number of bays. (2) The higher the reliability level is set when the structure is designed, the smaller the target value of the COF is required to limit the probability ratio to within a given tolerance level.
\end{abstract}

Keywords: Frame structure, total beam-hinging pattern mode, column overdesign factor(COF), reliability based design, performance function, stochastic limit analysis

骨組構造物、梁降伏先行型全体崩壊機構、柱・梁耐力比、信頼性設計、限界状態関数、確率極限解析

\section{1.はじめに}

骨組を梁降伏先行型全体崩壊機構となるように設計することは、 耐震設計上合理的と考えられている。なぜなら、骨組が全体崩罗に 至るまでに系全体として大きな塑性変形能力を発揮するため、大き な地震エネルギーを吸収することができるからである!1[2]。梁降伏 先行型全体崩壊機構を実現させるためには、梁の部材耐力よりも柱 の部材耐力を大きくし、梁に塑性ヒンジができるように柱・梁耐力 比(Column Overdesign Factor=COF)を決定しなければならない [2][3]。 しかし、骨組を確定論的に梁降伏先行型全体崩壊機構に設計した場 合でも、部材耐力の不確定性により、柱と梁の耐力のバランスが逆 転して設計時に想定していない崩壊機構が生じることがあり、必ず しも設計した崩壊形式で崩壊するとは限らない[3][4]。降伏耐力等の バラツキを考慮河した上で、梁降伏先行型全体崩壊機構を実現する ために重要な役割を果たす柱・梁耐力比（COF）のおおよその目標 值を設定し、その目標值以上で設計することによって、確定論的に 設計した場合にでも、梁降伏先行型全体崩壊機構からかけ離れる確 率をある值に収めることができれば、設計上有用である。

ある特定の骨組に対するCOF値に関する確率論的な評価はいくつ か提案されており (3]|44[6]、COFの基礎的性質がいくつか得られてい る。また、任意の多層多スパン骨組に対して確率極限解析法[7][8]に
よって骨組の最尤崩壊モードを検出し、梁降伏先行型全体崩壊機構 からかけ離れる確率をある值に収めるような目標COF值を確率論的 に評価した研究もある ${ }^{[9]}$ 。しかし、梁降伏先行型全体崩壊機構以外 は全て望ましくない崩壊機構であるという大変厳しい条件の下で評 価しているため、目標COFはスパン数や層数の增加に伴い、実設計 上では困難なほど大きな值となってしまう。

本論文ではまずある一定な信頼性レベルで梁降伏先行型全体崩壊 機構に設計された骨組に対して荷重とCOF値との関係を考察した。 その考察の結果に基づいて、三つの崩壊レベルで梁降伏先行型全体 崩壊機構からかけ離れる確率をある值に収めるような目標COF值を 評価し、目標信頼性指標、崩壊レベル、部材耐力の大きさ及び層数 とスパン数などによる目標COF値の変化を考察することを本論文の 目的とする。

\section{COFの定䉿と基本仮定}

本研究では、多層多スパン骨組における柱部材と梁部材が接合 する各節点のCOFを式(1)に示すように定義する。

$$
C_{o f}(k)=\sum_{l=1}^{n} M_{c l} / \sum_{l=1}^{n} M_{b l}
$$

* 名古屋工業大学 助教授・I博

** 名古屋工業大学 教授. 工博

$* * *$ 清水建設(㑣)技術研究所 主席研究員 $\cdot 工$ 工博

**** (侏熊谷組構造設計部工修
Assoc. Prof., Nagoya Institute of Technology, Dr. Eng.

Prof., Nagoya Institute of Technology, Dr. Eng.

Chief Research Engineer, Shimizu Co. Ltd., Dr. Eng.

Structural Engineering Dept., Kumagaigumi Co. Ltd., M. Eng. 
ただし、 $k$ は $k$ 番目の節点、 $M_{c l} 、 M_{b}$ はそれぞれ $k$ 番目の節点に接合 する柱部材、梁部材の終局耐力（全塑性モーメント）の平均值で ある。 $C_{o f}$ はCOFの值である。

各節点への柱耐力と梁耐力の配分の仕方により、骨組の性能は 当然変化するが、本研究では、研究の便宜をはかり、全節点にお いて同じCOF值を用い、構造物全体で一つのCOFとする。また、 本研究における解析対象骨組はスパンが $8 m$ 、階高が $4 m$ (首数は 1 7、スパン数は1 5)の鉄骨平面骨組で、最上階の梁耐力として の終局モーメントの平均值を $106.2 \mathrm{KN}-\mathrm{m}$ 、それ以外の梁耐力の平 均値を $212.4 K N-m$ とし、柱耐力の平均值はCOFをパラメータとし て変化させて決定する。なお、本研究の解析仮定を以下に示す。

(1)ラーメン骨組を構成する部材は、完全㴊塑性挙動をするものと する。

(2)外力は逆三角形分布をした静的水平地震荷重で、一定な信頼性 レベルで梁降伏先行型全体崩壊機構に設計された骨組を対象 とする。

(3)最上階の梁の部材耐力を $M_{p}$ 、それ以外の梁の部材耐力は、 $2 M_{p}$ とする。柱の部材耐力は、COFを変化させて決定する。

(4)全ての確率変数は相互独立な対数正規分布に従うものとする。 外力の変動係数は静的水平地震荷重を想定しているので、0.8 とし、部材耐力の変動係数は鉄骨骨組を想定して、0.1 とす る。

\section{3. 砰価手法}

\section{1 非正規分布を考慮した確率極限解析法}

梁降伏先行型全体崩壊機構からかけ離れる確率をある值に収める ことに必要なCOFを評価するために、まず骨組の最尤崩壊機構を探 索する必要がある。骨組の最尤崩壊機構を探索するには列挙法など いろいろあるが、大井等 ${ }^{[718]}$ が提案した確率極限解析法は比較的短 い計算時間で崩壊機構を探索することができる。ここでは、非正規 分布に従う外力・部材耐力を考慮するために、FORMを導入した確 率極限解析法 ${ }^{[6]}$ を用いて、骨組の最尤崩壊モードを探索する。その プロセスを以下に簡単に示す。

まず初期条件として部材の全塑性モーメントに平均值を与え、無 荷重の状態から平均外力への比例載荷を仮定して CP(Compact Procedure) を行う。CPの過程で得られる各崩壊モードに対して、 FORMに従って信頼性指標 $\beta$ 及び設計点を算定する。

ここで、解析上、上記プロセスにおいて適当な規㔼 $\beta \leq \beta_{\min }+\delta$ を導入する。そして、記憶された各設計点に対応する外力・部材全 塑性モ一メントの確定值を新たな外力・部材耐力として与え、再び $\mathrm{CP}$ を行う。最終的に新崩壊モードが出現しなくなるまで、解析は 進められるが、荷重係数入が 1 に到達しない場合は、その設計点は 破壊領域内にあることになり設計点としての要件を欠くので、除外 する。

\section{2 荷重レベルの取り扱い}

梁降伏先行型全体崩壊機構からかけ離れる確率は荷重の大きさに よって違うため、荷重レベルは目標COFを大きく左右する重要なパ ラメータとなる。本研究ではできるだけパラメータの数を少なくす るために、一定な信頼性レベルで設計した骨組を対象とし、荷重レ

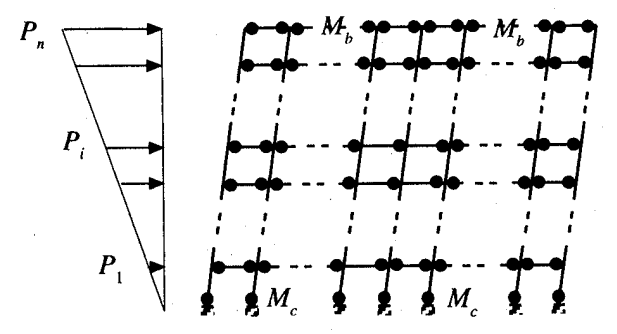

Fig. 1 Preferable Mode for $n$-story $m$-bay Frame

ベルは信頼性レベルによって設定する。即ち、同じ信頼性レベルの 下では、荷重の大きさはCOFによって変化する。以下COFによる荷 重の変化を考察する。

$n$ 層 $m$ スパンの骨組に対して設計目標とした梁降伏先行型崩壊モ一 ドはFig.1に示され、前述の基本仮定により、対応する限界状態関数 は次の一般式で容易に表せる。

$G(\mathbf{X})=2 \sum_{i=1}^{m} M_{b n i}+2 \sum_{j=1}^{n-1} \sum_{i=1}^{m} M_{b i j}+\sum_{l=1}^{2} M_{c s l}+\sum_{l=1}^{m-1} M_{c l}-\sum_{j=1}^{n} j h P_{j}$

ただし、 $M_{b i j}$ は第 $i$ スパン第 $j$ 層の梁の部材耐力であり、 $M_{c l}$ は中間柱 の部材耐力、 $M_{c s l}$ は外柱の部材耐力である。 $P_{j}$ は第 $j$ 層に作用する荷 重である。 $n, m$ は層数とスパン数であり、hは階高である。前述の基 本仮定により、 $M_{b i j}, M_{c l}, M_{c s l}, P_{j}$ は全て相互独立な対数正規確率変数 であり、それらの平均值に式(3)の関係があり、変動係数には式(4) の関係がある。

$$
\begin{array}{lrl}
\mu_{b n i}=\mu_{b} \quad \mu_{b i j}=2 \mu_{b} & \\
\mu_{c s l}=C_{o f} \mu_{b} \quad \mu_{c l}=2 C_{o f} \mu_{b} & \mu_{p j}=j \mu_{p} \\
V_{b n i}=V_{b i j}=V_{c l}=V_{c s l}=V_{1} & V_{p j}=V_{2}
\end{array}
$$

ただし、 $\mu_{b}$ は梁の部材耐力の平均值であり、 $\mu_{p}$ は第1層に作用する荷 重の平均值である。 $V_{1}, V_{2}$ はそれぞれ耐力と荷重の変動係数である。

前述の基本仮定により、 $V_{2}$ より $V_{1}$ がかなり小さいため、式(2)の限 界状態関数に対応する 2 次モーメント信頼性指標は次式で表される （付録参照）。

$$
\beta_{S M} \approx \frac{2 m(2 n-1) \mu_{b}+2 m C_{o f} \mu_{b}-\mu_{p} h \sum_{j=1}^{n} j^{2}}{V_{2} \mu_{p} h \sqrt{\sum_{j=1}^{n} j^{4}}}
$$

即ち、第1層に作用する荷重の平均値 $\mu_{p}$ は次式で表される。

$$
\mu_{p} \approx \frac{2 m \mu_{b}\left(2 n-1+C_{o f}\right)}{h\left(\beta_{S M} V_{2} \sqrt{\sum_{j=1}^{n} j^{4}}+\sum_{j=1}^{n} j^{2}\right)}
$$

$V_{2}$ より $V_{1}$ がかなり小さいため、同じ信頼性レベルの下では、 $\beta_{S M}$ は COFからほぼ影響を受けない（付録参照）ので、 $\mu_{p}$ はほぼ $C_{o f}$ の線形 関数であることが分かる。

また、同じ信頼性レベルの下では、 $\beta_{S M}$ は部材耐力 $\mu_{b}$ およびスパン 数 $m$ にもよらずほぼ一定值を保つようになっている（付録参照） ので、 $\mu_{p}$ は $\mu_{b}$ および $m$ とほぼ正比例になることが分かる。

2層多スパン骨組を例とし、COFが変化してもFORM 信頼性指 標 $\beta=2$ を保つように荷重の平均值を計算し、得られた $\mu_{\rho}$ とCOFの関 係をFig.2に示す。Fig.2により $\mu_{p}$ は $C_{o f}$ とほぼ線形関係になることが 


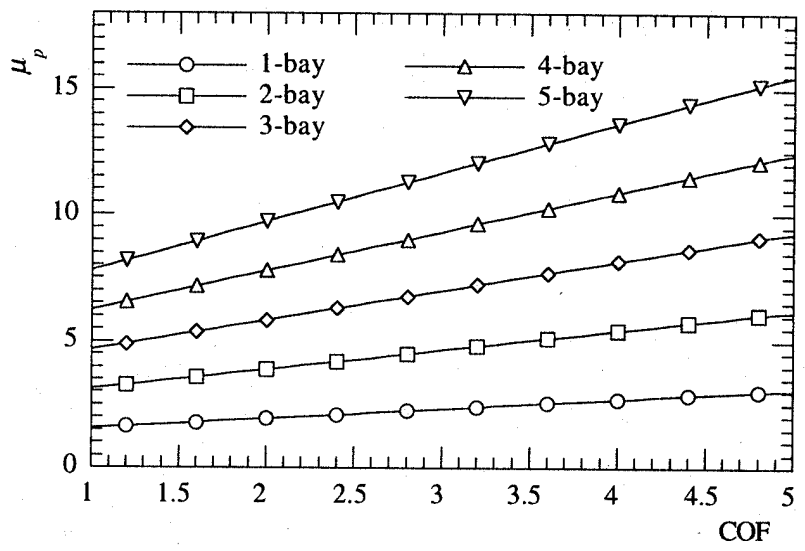

Fig.2 Relation between COF and Load

分かる。

\section{$3.3 \gamma$ COF曲䋛によるCOF俩価手法}

本研究では、既に一定な信頼性レベルで梁降伏先行型全体崩壊 機構に設計された骨組を想定し、上述の FORM を導入した確率極 限解析法により、最も出現しやすいいくつかの崩壊機構を抽出す る。そして、式(7)に示すように望ましくない崩壊機構の出現確率と 望ましい梁降伏先行型全体崩壊機構の出現確率の割合を評価指標 として用いる。

$$
\gamma=\frac{P_{f 2}}{P_{f 1}}
$$

ただし、 $P_{f 1}$ は望ましい梁降伏先行型崩壊機構の出現確率、 $P_{f 2}$ は望 ましくない崩壊機構の中で最も出現しやすい崩壊機構の出現確率 を表す。ねは望ましくない崩壊機構の相対的な出現確率を表す評価 指標である。

骨組を梁降伏先行型崩壊機構で設計し、設計した崩壊機構の出 現を確率論的な意味で保証するために、評価指標 $\gamma$ は(8)式に示す ように明確なレベル $\gamma_{0}$ 以内におさめなければならない。

$$
\gamma=\frac{P_{f 2}}{P_{f 1}} \leq \gamma_{0}
$$

ただし、 $\gamma_{0}$ は評価指標 $\gamma$ の許容レベルとしての目標值であり、以下 目標評価指標という。

一つのCOFの值に対して(6)式に示すように荷重の平均值が設定 され、確率極限解析法により最も出現しやすいいくつかの崩壊機 構を抽出される。そして、式(7)に対応する望ましい崩壊機構の出現 確率 $P_{f 1}$ と望ましくない崩壊機構の出現確率 $P_{f 2}$ が得られ、一つの評 価指標 重の平均值を変化させ、評価指標 $\gamma$ とCOFの関係を表す $\gamma$-COF 曲線 が得られる。 $\gamma$-COF曲線により目標評価指標 $\gamma_{0}$ に対応するCOFの值 を求め、目標となるCOF值（以下目標COF值という）とする。

いうまでもなく、上述の方法で得られた目標COFは目標評価指標 $\gamma_{0}$ によって大きく変化する。そこで指標 $\gamma_{0}$ は明確な值を示すべきで あるが、設計に受け入れられることができるレベル $\gamma_{0}$ はまだ明らか ではないので、本研究では初期的な検討として、 $\gamma_{0}=0.9$ と設定し、 望ましくない崩壊機構の出現確率は望ましい崩壊機構の出現確率 の 90\%以内に納めるような目標COF を考察する。

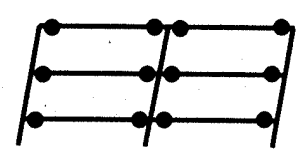

Fig.3 Type of Tolerable Collapse Mode for Level I

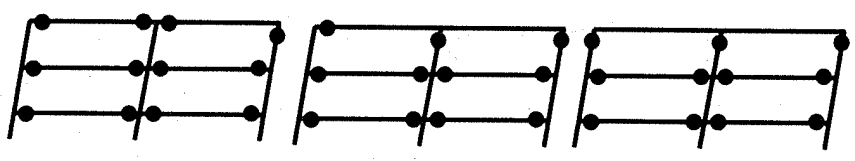

Fig.4 Type of Tolerable Collapse Modes for Level II

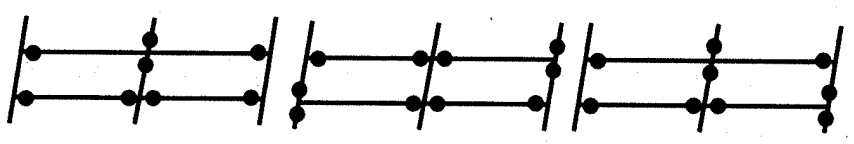

Fig.5 Type of Tolerable Collapse Modes for Level III

また、評価指標 $\gamma$ は相対的な指標であるため、望ましくない崩壊 機構をどのように設定するかにより変化する。文献[9]は梁降伏先 行型全体崩壊機構以外は全て望ましくない崩壊機構であるという 大変厳しい条件の下で評価しているため、目標COFはスパン数や 総数の增加に伴い、実設計上では困難なほど大きな值となってし まう。耐震設計では、大きな地震エネルギを吸収する崩壊機構が 望ましいので、本研究では厳しい梁降伏先行型全体崩壊機構のみ にこだわらず、設計上有効な崩壊機構を次の 3 つのレベルに分け て検討する。

レベル I：厳密な梁降伏先行型全体崩壊機構

レベル II : ほぼ梁降伏先行型全体崩壊機構

レベルIII : 全体崩壊機構

レベル I ではFig.3に示すように全層の梁にのみ塑性ヒンジが発 生する場合以外は全て望ましくない崩壊機構とする。レベル II で はFig.4に示すように梁と最上層の柱頭部にのみ塑性ヒンジが発生 する場合、ほぼ梁降伏先行型全体崩壊機構として許容され、それ とレベルIの厳密な梁降伏先行型全体崩壊機構以外は全て望まし くない崩壊機構とする。レベルIIIではFig.5に示すように梁と中間 層の一部の柱に塑性ヒンジが発生しても全体崩壊機構であれば許 容され、それとレベルIの厳密な梁降伏先行型全体崩壊機構およ びレベル II のほぼ梁降伏先行型全体崩壊機構以外は全て望ましく ない崩壊機構とする。

\section{4 目标COFの証倒}

2 層2 スパン骨組を例とし、評価プロセスを説明する。目標信頼 性指標を $\beta=2$ とし、COF=1.14の時、確率極限解析により、Fig.6に 示すような最も出現しやすい 6 つの崩壊機構が得られ、出現確率 の大きい順にモード1, 2, 3, 4, 5, 6とする。6つの崩壊機構の中で は、望ましい崩壊機構はモード1であり、レベル I，II，IIIに対応 する式(7)のP $f:$ は全てモード1の出現確率となる。崩壊レベル I 、 II、IIにおいて望ましくない崩壊機構の中で最も出現しやすい崩壊 機構は、それぞれモード2、3、4であり、レベル I 、II，IIIに対応 する式(7)のP $P_{\Omega}$ はそれぞれモード2、3、4の出現確率となる。 


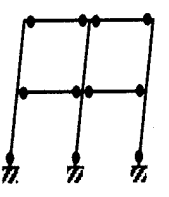

Mode 1

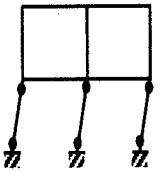

Mode 4

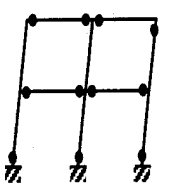

Mode 2

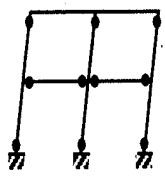

Mode 5

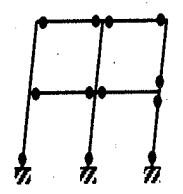

Mode 3

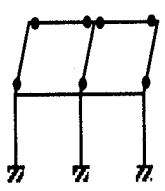

Mode 6

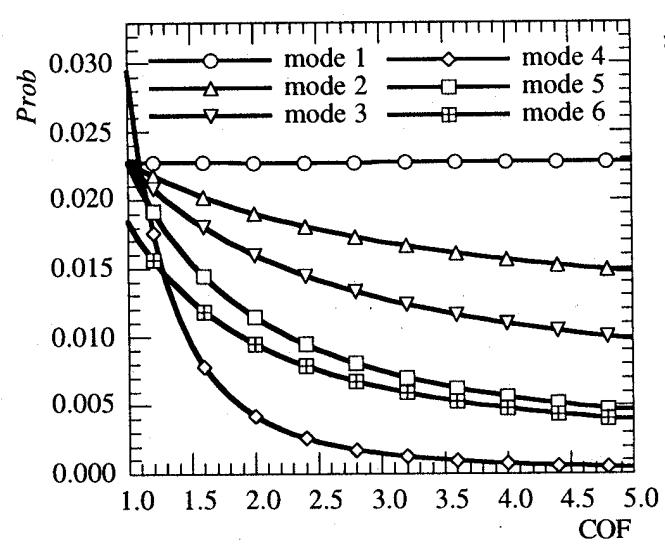

Fig.7 Relation between COF and the Failure Probabilities

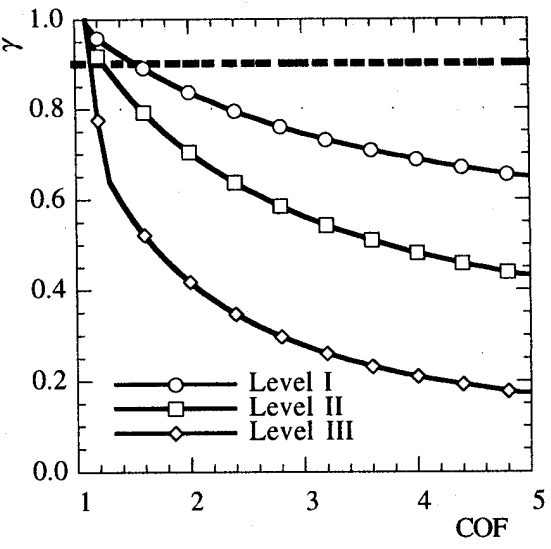

Fig. $8 \gamma$ COF Curves

Fig.6 Likely Colallaps Modes

the Three Levels

Table 1 Corresponding Unprefere modes in the Three Levels

\begin{tabular}{|l|c|c|c|c|c|}
\hline COF & $1.09 \sim 1.105$ & $1.105 \sim 1.12$ & $1.12 \sim 1.15$ & $1.15 \sim 1.28$ & $1.28 \sim$ \\
\hline order of & $1-4-2-$ & $1-2-4-$ & $1-2-3-$ & $1-2-3-$ & $1-2-3-$ \\
modes & $3-5-6$ & $3-5-6$ & $4-5-6$ & $5-4-6$ & $5-6-4$ \\
\hline Level I & mode 4 & mode 2 & mode 2 & mode 2 & mode 2 \\
\hline Level II & mode 4 & mode 4 & mode 3 & mode 3 & mode 3 \\
\hline Level III & mode 4 & mode 4 & mode 4 & mode 4 & mode 6 \\
\hline
\end{tabular}

COFを1.0から5.0まで変化させ、確率極限解析により、得られ た最も出現しやすい 6 つの崩壊機構がFig.6に示す各崩壊機構と同 じであるが、COFの変化によって各モードの出現しやすさが変わ る。考察するために、COFの変化によってFig.6に示す各崩壊機構 の出現確率の変化をFig.7に示す。Fig.7により、COFが非常に小さ いとき、一番出現しやすいのはモード4であり、COF=1.09 となる と、望ましい崩壊機構モード1 は一番出現しやすくなる。本研究 では、既に梁降伏先行型全体崩壊機構に設計された骨組を想定し ており、 $\mathrm{COF}<1.09$ 範囲は考察の対象外となる。COF=1.09-1.105 の範囲では各崩壊機構の出現する順番は1-4-2-3-5-6となり、レべ ル I、II、IIIに対応する式(7)のP $P_{2}$ は全てモード4の出現確率とな る。

C O F の増加によって各崩壊機構の出現する順番およびレベル I、II、IIIで $P_{f 2}$ に対応するモードをTable 1 に示す。表中、COF= 1.15 - 1.28の範囲ではモード5の出現確率はモード4のそれを上回っ ているものの、モード5 はレベルIIIで許容される崩壊型であるた め、レベルIII で $P_{f 2}$ に対応するモードはモード4である。COF $>1.28$ の時、モード6の出現確率はモード4のそれを上回っており、レベ， ルIII で $P_{\Omega}$ に対応するモードはモード6となる。

Fig.8に各崩壊レベルに対応する評価指標 $\gamma$ とCOFの関係を表す $\gamma$-COF曲線を示す。図中、各曲線の折点は $P_{f 2}$ に対応するモ一ドの 入れ代わるところを表す。例えば、レベルIII では、 COF $<1.28$ と $\mathrm{COF}>1.28$ の時、 $P_{f 2}$ に対応するモードはそれぞれモード4と5であ るので、 $\gamma$-COF曲線のCOF=1.28のところで一つの折点が生じる。 目標COF值は、レベル I、II、III $\sigma \gamma$-COF曲線と $\gamma_{0}$ 水平線の交点 のCOF値を $1.55,1.25,1.14$ として求められ、レベル I 、II 、IIIの順 に目標COF值が小さくなることが分かる。

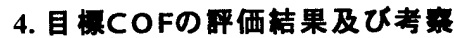

ここでは多層多スパン骨組を対象とし、目標信頼性指標、崩堎 レベル及び層数とスパン数による目標 $\mathrm{COF}$ 值の変化を考察する。

\section{1 崩壊レベルIIにおけるスパン数による目標COF值への影䛠}

崩壊レベルIII ではFig.5に示すように梁と中間層の一部の柱に塑 性ヒンジが発生しても全体崩壊機構であれば許容され、式(7)のP $P_{f 2}$ に対応する望ましくない崩壊機構は層崩壊モードとなる。層崩壊 モードは基本的にはFig.9a とbに示すような形であり、対応する限 界状態関数はそれぞれ式(9)と(10)で表わされる。

$$
\begin{aligned}
G(\mathbf{X})=2 \sum_{j=1}^{n} \sum_{i=1}^{-1} M_{b i j}+\sum_{i=1}^{4} M_{c s l}+\sum_{l=1}^{2 m} M_{c l}^{2} \\
-\sum_{j=1}^{n c} j h P_{j}-\sum_{j=n c+1}^{n} n_{c} h P_{j} \\
G(\mathbf{X})=2 \sum_{i=1}^{m} M_{b r i}+2 \sum_{j=n-n c+1}^{n} \sum_{i=1}^{m} M_{b i j} \\
+\sum_{l=1}^{2} M_{c s l}+\sum_{i=1}^{m-1} M_{c l}-\sum_{j=n-n c+1}^{n}\left(j+n_{c}-n\right) h P_{j}
\end{aligned}
$$

ただし、nは層崩壊モードにおける崩壊した層数である。

式(9)と(10)の限界状態関数に対応する 2 次モーメント信頼性指 標はそれぞれ式(11)と(12)のように求められる。

$$
\beta_{S M} \approx \frac{4 m\left(n_{c}-1+C_{o f}\right) \mu_{b}-\mu_{p} h\left(\sum_{j=1}^{n_{c}} j^{2}+n_{c} \sum_{j=n_{c}+1}^{n} j\right)}{V_{2} \mu_{p} h \sqrt{\sum_{j=1}^{n_{c}} j^{4}+n_{c}^{2} \sum_{j=n_{c}+1}^{n_{c}} j^{2}}}
$$

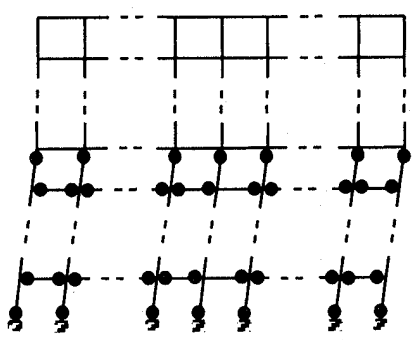

(a)

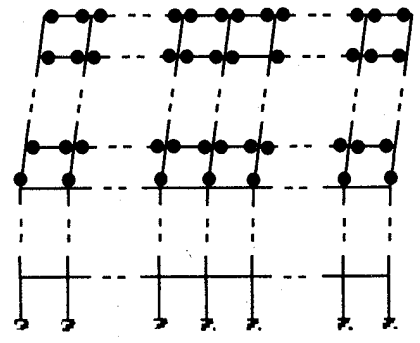

(b)
Fig.9 Unpreferable Modes for Level III 


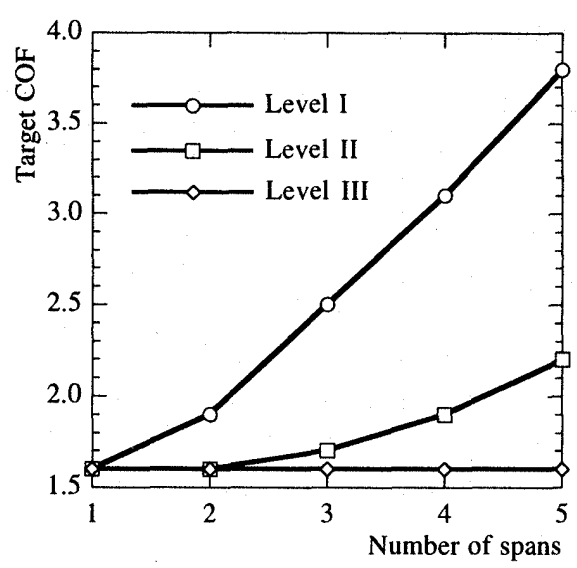

Fig. 10 Target COF for Level III

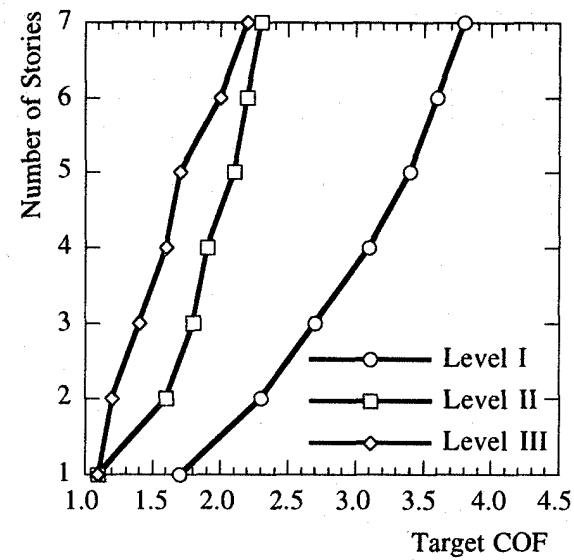

Fig.11 Target COF for 4 storey multibay Frame

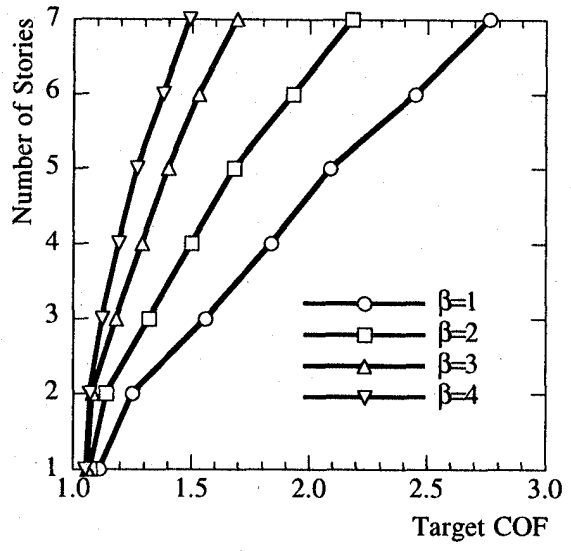

Fig.12 Target COF for 4-bay multistorey Frame

$$
\beta_{S M} \approx \frac{2 m\left(2 n_{c}-1+C_{o f}\right) \mu_{b}-\mu_{p} h \sum_{j=n-n_{c}+1}^{n} j\left(j+n_{c}-n\right)}{V_{2} \mu_{p} h \sqrt{\sum_{j=n-n_{c}+1}^{n} j^{2}\left(j+n_{c}-n\right)^{2}}}
$$

同じ信頼性レベルの下では、3.2節に示すように荷重の平均值 $\mu_{p}$ はスパン数 $m$ と正比例になっているので、式(11)と(12)の $\beta_{S M}$ は $m$ に依存しないことが分かる。また、付録と同様に式(9)と(10)の 限界状態関数の高次モーメント $\alpha_{G k}$ を求めると、 $\alpha_{G k}$ もスパン数 $m$ に依存しないことが分かる。従って、式(9)と(10)の限界状態関 数に対応する信頼性指標あるいは破壊確率は $m$ に依存しない。即 ち、同じ信頼性レベルの下では、スパン数 $m$ を変化させても、式 (7)のP $P_{f}$ は同じであるので、レベルIIIで、目標COFは $m$ に依存 しないことが分かる。

目標信頼性指標を $\beta=2$ とし、 4 層骨組の目標COFのスパン数に よる変化をFig.10に示す。Fig.10より、崩壊レベル I とII では、 目標C O F 值がスパン数が多くなるにつれて大きくなっている が、崩壊レベルIII゙はスパン数によらずに同一の值となる。

\section{2 部材耐力の平均値等による目標COF値への影響}

本論文の基本仮定では最上階の梁耐力の平均值を $106.2 \mathrm{KN}-\mathrm{m}$ と設定したが、ここでは、部材耐力の平均値による目標C OFへ の影響を検討する。一定な信頼性レベルで梁降伏先行型全体崩 壊機構に設計された骨組に対して、出現しやすい崩壊機構はい ろいろあるが、式(5)(11)(12)に示すように、あらゆる崩壊機構に 対応する 2 次モーメント信頼性指標は次式で表すことができ る。

$$
\beta_{S M} \approx \frac{a \mu_{b}-b \mu_{p}}{c \mu_{p}}
$$

ただし、 $a, b, c$ は層数、スパン数および崩壊機構の種類に依存す る係数である。

同じ信頼性レベルの下では、3.2節に示すように荷重の平均値 $\mu_{p}$ はスパン数 $m$ と正比例になっているので、式(13)の $\boldsymbol{\beta}_{s M}$ は $\mu_{b}$ に依 存しないことが分かる。また、付録と類似するように式( 9 ) と
(10)のような各崩壊機構の限界状態関数の高次モーメント $\alpha_{G k}$ を求 め、 $\alpha_{G k}$ はスパン数 $m$ にも依存しないことが分かる。即ち、同じ信 頼性レベルの下では、各崩壊機構に対応する信頼性指標あるいは 破壊確率は $\mu_{b} に$ 依存しない。従って、本研究で得られた目標COFは $\mu_{b}$ に依存しないことが分かる。

また、本研究では鈶直荷重を考虑していないので、どの崩買機 構に対応する限界状態関数にはスパンの大きさを含めていない。 従って、本研究で得られた目標C O F はスパンの大きさにも依存し ないことがわかる。

\section{3 信頼性レベルなどによる目標COF值への影鰵}

目標信頼性指標を $\beta=2$ と設定し、4スパン骨組の目標COFの層数 による変化をFig.11に示す。Fig.11より、崩壊レベル I，II，II とも に層数が多くなるにつれて目標C OF 值が大きくなり、崩壊レベル I 、II，IIIの順に目標C OF值が小さくなることがわかる。これは崩 壊レベル I， I， IIIの順に許容される崩壊機構の制限は緩んでいる からである。

崩壊レベルを而と設定し、目標信頼性指標 $\beta=1,2,3,4$ の場合の目 標COF値の層数による変化をFig.12に示す。Fig.12により目標COF 値は目標信頼性レベルによって大きく変化しており、目標信頼性 レベルが高くなるにつれて、目標C O F 值が小さくなることがわか る。これは目標信頼性レベルが高くなるにつれて、耐力の平均值 が荷重の平均值から離れており、部材耐力のバラツキ（変動倸 数）の影響が相対的に弱くなり、柱と梁の耐力のバランスが逆転 する可能性が小さくなるからである。

\section{4 目㭺COFの释価結果}

ここでは、7層5 スパンまでの多層多スパンの骨組を対象とし、 目標信頼性指標 $\beta=1,2,3,4$ 之設定し、崩壊レベル I，II，IIIの順に目 標COF值の評価結果をそれぞれTable 2,3,4に示す。

\section{5. 結暗}

本研究の考察より、以下のような結論が得られた。

(1) 本研究の仮定では、崩壊レベル I、IIにおいては、スパン数が 多くなるにつれて目標C OF 值が大きくなるが、崩壊レベル亚に 
Table 2 Target COF for Level $\mathrm{I}\left(\gamma_{0}=0.9\right)$

\begin{tabular}{|c|c|c|c|c|c|c|}
\hline reliability levels & stories & 1-bay & 2-bay & 3-bay & 4-bay & 5-bay \\
\hline \multirow[t]{7}{*}{$\beta=1$} & 1-story & 1.22 & 1.49 & 1.83 & 2.29 & 2.92 \\
\hline & 2-story & 1.38 & 1.84 & 2.41 & 3.13 & 4.06 \\
\hline & 3 -story & 1.57 & 2.08 & 2.78 & 3.63 & 4.69 \\
\hline & 4-story & 1.84 & 2.25 & 3.04 & 3.97 & $>5$ \\
\hline & 5 -story & 2.09 & 2.39 & 3.24 & 4.23 & $>5$ \\
\hline & 6-story & 2.45 & 2.51 & 3.42 & 4.46 & $>5$ \\
\hline & 7-story & 2.76 & 2.77 & 3.57 & 4.65 & $>5$ \\
\hline \multirow[t]{7}{*}{$\beta=2$} & 1-story & 1.14 & 1.29 & 1.46 & 1.68 & 1.92 \\
\hline & 2-story & 1.25 & 1.55 & 1.86 & 2.24 & 2.67 \\
\hline & 3 -story & 1.36 & 1.73 & 2.17 & 2.68 & 3.25 \\
\hline & 4-story & 1.50 & 1.90 & 2.43 & 3.03 & 3.71 \\
\hline & 5-story & 1.68 & 2.03 & 2.64 & 3.31 & 4.06 \\
\hline & 6-story & 1.93 & 2.15 & 2.81 & 3.54 & 4.35 \\
\hline & 7-story & 2.18 & 2.24 & 2.94 & 3.72 & 4.57 \\
\hline \multirow[t]{7}{*}{$\beta=3$} & 1-story & 1.10 & 1.20 & 1.31 & 1.45 & 1.59 \\
\hline & 2-story & 1.18 & 1.38 & 1.61 & 1.85 & 2.13 \\
\hline & 3-story & 1.26 & 1.55 & 1.87 & 2.22 & 2.61 \\
\hline & 4-story & 1.34 & 1.71 & 2.11 & 2.55 & 3.04 \\
\hline & 5 -story & 1.40 & 1.85 & 2.33 & 2.85 & 3.43 \\
\hline & 6-story & 1.55 & 1.97 & 2.52 & 3.12 & 3.78 \\
\hline & 7-story & 1.69 & 2.09 & 2.70 & 3.37 & 4.09 \\
\hline \multirow[t]{7}{*}{$\beta=4$} & 1-story & 1.08 & 1.16 & 1.24 & 1.33 & 1.43 \\
\hline & 2-story & 1.14 & 1.29 & 1.46 & 1.64 & 1.84 \\
\hline & 3 -story & 1.21 & 1.44 & 1.68 & 1.94 & 2.23 \\
\hline & 4-story & 1.27 & 1.57 & 1.89 & 2.23 & 2.60 \\
\hline & 5-story & 1.33 & 1.70 & 2.09 & 2.51 & 2.96 \\
\hline & 6-story & 1.39 & 1.82 & 2.28 & 2.77 & 3.29 \\
\hline & 7-story & 1.50 & 1.94 & 2.46 & 3.02 & 3.62 \\
\hline
\end{tabular}

Table 4 Target COF for Level III $\left(\gamma_{0}=0.9\right)$

\begin{tabular}{|c|c|c|c|c|}
\hline reliability levels & $\beta=1$ & $\beta=2$ & $\beta=3$ & $\beta=4$ \\
\hline 1-story & 1.11 & 1.07 & 1.06 & 1.05 \\
2-story & 1.25 & 1.14 & 1.08 & 1.07 \\
3-story & 1.56 & 1.32 & 1.18 & 1.12 \\
4-story & 1.84 & 1.50 & 1.29 & 1.19 \\
5-story & 2.09 & 1.68 & 1.40 & 1.27 \\
6-story & 2.45 & 1.93 & 1.53 & 1.38 \\
7-story & 2.76 & 2.18 & 1.69 & 1.49 \\
\hline
\end{tabular}

おいてはスパン数によらず一定である。

（2）崩壊レベル I 、II、II ともに層数が増えると、目標COF值は大 きくなる。また、崩壊レベル I 、II 、III の順に目標COF値は小 さくなる。

(3)目標COF值は目標信頼性レベルによって大きく変化しており、 目標信頼性レベルが高くなるにつれて目標C O F 值は小さくな る。

(4)本研究の仮定では、目標COFは部材耐力の大きさおよびスパン の大きさに依存しない。

本研究では、既に一定な信頼性レベルで梁降伏先行型全体崩壊 機構に設計された骨組に対して、目標信頼性指標、崩壊レベル、
Table 3 Target COF for Level II $\left(\gamma_{0}=0.9\right)$

\begin{tabular}{|c|c|c|c|c|c|c|}
\hline reliability levels & stories & 1 -bay & 2 -bay & 3-bay & 4-bay & 5 -bay \\
\hline$\beta=1$ & 1-story & 1.11 & 1.11 & 1.11 & 1.11 & 1.11 \\
& 2-story & 1.25 & 1.38 & 1.60 & 1.84 & 2.11 \\
& 3-story & 1.56 & 1.57 & 1.77 & 2.08 & 2.41 \\
& 4-story & 1.84 & 1.84 & 1.90 & 2.25 & 2.63 \\
& 5-story & 2.09 & 2.09 & 2.09 & 2.39 & 2.80 \\
& 6-story & 2.45 & 2.45 & 2.45 & 2.51 & 2.95 \\
& 7-story & 2.76 & 2.76 & 2.76 & 2.77 & 3.08 \\
\hline$\beta=2$ & 1-story & 1.07 & 1.07 & 1.07 & 1.07 & 1.07 \\
& 2-story & 1.16 & 1.25 & 1.39 & 1.53 & 1.69 \\
& 3-story & 1.32 & 1.36 & 1.53 & 1.74 & 1.95 \\
& 4-story & 1.50 & 1.50 & 1.66 & 1.90 & 2.16 \\
& 5-story & 1.68 & 1.68 & 1.76 & 2.03 & 2.33 \\
& 6-story & 1.93 & 1.93 & 1.95 & 2.15 & 2.47 \\
& 7-story & 2.18 & 2.18 & 2.18 & 2.24 & 2.59 \\
\hline$\beta=3$ & 1-story & 1.06 & 1.06 & 1.06 & 1.06 & 1.06 \\
& 2-story & 1.09 & 1.18 & 1.28 & 1.38 & 1.49 \\
& 3-story & 1.18 & 1.26 & 1.40 & 1.55 & 1.71 \\
& 4-story & 1.29 & 1.34 & 1.52 & 1.71 & 1.90 \\
& 5-story & 1.40 & 1.40 & 1.62 & 1.85 & 2.08 \\
& 6-story & 1.53 & 1.55 & 1.72 & 1.97 & 2.24 \\
& 7-story & 1.69 & 1.69 & 1.80 & 2.09 & 2.39 \\
\hline$\beta=4$ & 1-story & 1.05 & 1.05 & 1.05 & 1.05 & 1.05 \\
& 2-story & 1.08 & 1.14 & 1.22 & 1.30 & 1.38 \\
& 3-story & 1.12 & 1.21 & 1.32 & 1.44 & 1.56 \\
& 4-story & 1.19 & 1.27 & 1.42 & 1.57 & 1.73 \\
& 5-story & 1.27 & 1.34 & 1.52 & 1.70 & 1.89 \\
& 6-story & 1.38 & 1.40 & 1.61 & 1.82 & 2.05 \\
& 7-story & 1.49 & 1.49 & 1.69 & 1.94 & 2.20 \\
\hline
\end{tabular}

部材耐力の大きさおよび層数とスパン数などによる目標COF値の 変化を考察した。目標COF值に大きな影響を与えるさまざまな要 因として、評価レベルとしての目標評価指標、部材耐力の間の相 関性、地震荷重の分布、骨組の動的挙動、鈶直力の大きさなどが 考えられる。今後、変動係数の大きさを含めて、これらの要因を 総合的に考虑し、目標COF值を評価、検討する必要がある。

\section{謝辞}

本研究の数值解析について、元名古屋工業大学大学院生の奥山 隆氏（松下電工）と上里智之氏（竹中工務店）及び元名古屋工業 大学学生の落合慎吾氏（名鉄エーゼンシー）に負うところが多 い。付して感謝します。

\section{参考文献}

[1] 日本建築学会、建築耐震設計における保有耐力と変形性能、 1990.10 .

[2]河野昭彦、松井千秋、他、SRC 構造多㕌ラーメン架構の全体崩墙機構 形成に要求される柱梁耐力比の基礎的性質、日本建築学会構造系論文 集、No.505, 153-160, 1998.3.

［3］桑村仁、佐々木道夫、加藤勉、降伏耐力のばらつきを考慮した全体崩塤 メカニズムの設計、日本建築学会構造系論文集、No.401, 1989.7.

[4] 諏訪仁、鈴木哲夫、他、梁降伏型骨組の耐震信頼性評価に関する一手法、 JCOSSAR' $95,425-430$.

[5] 日本建築学会、建築物の限界状態設計指針（案)、第一版、2000.3.

[6] 小野徹郎、趙衍㴊、吉原和宏、確率極限解析法を用いた平面骨組構造物 
の COF 評価法、構造工学論文集、Vol. 43B, 377-382, 1997.3

[7] 大井謙一、骨租の確率極限解析、JCOSSAR'91, 675-678.

[8] 西田明美、孫宏、大井謙一、高梨晃一、骨組の崩壤モード探索に関する 一考察、JCOSSAR'95, 239-242, 1995.11

[9] Ono, T., Zhao, Y.G. and Ito, T., Probabilistic Evaluation of Column Overdesign Factors for Frames, J. of Structural Engineering, ASCE, Vol. 126, No. 5, 605-611, 2000.4.

[10] Zhao, Y.G. and Ono, T., Third-moment standardization for structural reliability analysis, J. Struct. Engrg, ASCE, Vol. 126, No. 6, 724-732, 2000.6

付録 : 荷重一 COF関係の証明

次の変数代替を行い、

$$
\begin{aligned}
& x_{b}=2 \sum_{i=1}^{m} M_{b n i}+2 \sum_{j=1}^{n-1} \sum_{i=1}^{m} M_{b i j} \\
& x_{c}=\sum_{l=1}^{2} M_{c s l}+\sum_{l=1}^{m-1} M_{c l} \\
& x_{p}=\sum_{j=1}^{n} j h P_{j}
\end{aligned}
$$

式(2)の限界状態関数は式(17)のようになる。

$$
G(\mathbf{X})=x_{b}+x_{c}-x_{p}
$$

式(3)(4)により、 $x_{b}, x_{c}, x_{p}$ の平均値と標準偏差は次式のように得ら れる。

$$
\begin{array}{ll}
\mu_{x b}=2 m(2 n-1) \mu_{b} & \sigma_{x b}=2 V_{1} \mu_{b} \sqrt{m(4 n-3)} \\
\mu_{x c}=2 m C_{o f} \mu_{b} & \sigma_{x c}=V_{1} \mu_{b} C_{o f} \sqrt{2(2 m-1)} \\
\mu_{x p}=\mu_{p} h \sum_{j=1}^{n} j^{2} & \sigma_{x p}=V_{2} \mu_{p} h \sqrt{\sum_{j=1}^{n} j^{4}}
\end{array}
$$

式(18)(19)(20)により、式(17)の限界状態関数の平均值は次式のよ うに得られる。

$$
\mu_{G}=2 m(2 n-1) \mu_{b}+2 m C_{o f} \mu_{b}-\mu_{p} h \sum_{j=1}^{n} j^{2}
$$

$V_{2}$ より $V_{1}$ が大分小さいため、式(2)の限界状態関数の標準偏差 $\sigma_{G}$ が 次式のように近似的に表される。

$$
\sigma_{G}=\sqrt{\sigma_{x b}^{2}+\sigma_{x c}^{2}+\sigma_{x p}^{2}} \approx \sigma_{x p}=V_{2} \mu_{p} h \sqrt{\sum_{j=1}^{n} j^{4}}
$$

即ち、式(2)の限界状態関数に対応する 2 次モーメント信頼性指標 は式(5)のように近似的に表される。

なお、限界状態関数 $Z=G(\mathbf{X})$ の分布形はそのモーメントと直接関 係があり、 $G(\mathbf{X})<0 に$ 対応する信頼性指標または破壊確率も $Z=G(\mathbf{X})$ のモーメントの関数である ${ }^{[10) 。 こ こ て ゙ は 、 ~} Z=G(\mathbf{X})$ の標準化確率変 数 $x_{S}=\left(Z-\mu_{G}\right) / \sigma_{G}$ と標準正規確率変数 $u$ の間に次式の関係があると仮定 する。

$$
u=N\left(x_{S},\left\{\alpha_{G k}\right\}\right)
$$

ただし、 $N$ は $x_{s}$ とuの関係を表す関数であり、 $\alpha_{G k}$ は $Z=G(\mathbf{X})$ の無次元 $k$ 次中心モーメントである。

式(24)の破壊確率の定義より信頼性指標は式(25)のように与えて いる。

$$
\begin{aligned}
& \operatorname{Prob}[G \leq 0]=\operatorname{Prob}\left[x_{s} \leq-\frac{\mu_{G}}{\sigma_{G}}\right]=\operatorname{Prob}\left[x_{s} \leq-\beta_{S M}\right] \\
& \beta=-N\left(-\beta_{S M},\left\{\alpha_{G k}\right\}\right)
\end{aligned}
$$

$V_{2}$ より $V_{1}$ が大分小さいため、 $Z=G(\mathbf{X})$ の無次元 $k$ 次中心モーメン ト $\alpha_{G k}$ が次式のように近似的に表される。

$$
\alpha_{G k}=\frac{\alpha_{x b k} \sigma_{x b}^{k}+\alpha_{x c k} \sigma_{x c}^{k}+\alpha_{x p k} \sigma_{x p}^{k}}{\sigma_{G}^{k}} \approx \alpha_{x p k}
$$

$$
\alpha_{x p k}=\frac{\alpha_{p k} \sum_{j=1}^{n} j^{2 k}}{\left(\sum_{j=1}^{n} j^{4}\right)^{k / 2}}
$$

ただし、 $\alpha_{x b k}, \alpha_{x c k}, \alpha_{x p k}$ はそれぞれ $x_{b}, x_{c}, x_{p}$ の無次元 $k$ 次中心モーメン トであり、 $\alpha_{p k}$ は第1層に作用する荷重の無次元 $k$ 次中心モーメントで ある。式 (26) と (27) により、 $\alpha_{G k}$ は COF とほぼ関保ないことが分か る。従って、COFを変化させても、式(25)の信頼性指標が一定值を 保つために、2 次モーメント信頼性指標 $\beta_{S M}$ も COFによらず一定值 を保たなければならない。

また、式(26)と(27)により、 $\alpha_{G k}$ は部材耐力 $\mu_{b}$ およびスパン数 $m$ に もほぼ関係ないことが分かる。従って、的および $m$ にを変化させて も、一定值の信頼性指標で設定すれば、2 次モーメント信頼性指標 $\beta_{S M}$ も $\mu_{b}$ および $m$ の変化によらず一定值を保つようになる。 